\title{
ANALYSIS OF THE CHANNEL AND MARKETING EFFICIENCY OF LADY FINGER BANANA FARMING IN ARISAN GADING VILLAGE, SOUTH INDRALAYA SUBDISTRICT OF OGAN ILIR DISTRICT, INDONESIA
}

\author{
Mulyana Eka \\ JI. Raya Palembang-Prabumulih KM 32 North Indralaya Ogan Ilir, South Sumatra, Indonesia \\ E-mail: eka.agri@gmail.com
}

\begin{abstract}
Banana is a horticulture commodity that can grow in various types of land. Banana production and cultivation also do not require large capital. People cultivate bananas with various planting systems such as intercropping, monoculture, mixed plants, or as hedgerows. The result this study: 1) the marketing channel of Lady Finger Banana in Arisan Gading Village had three marketing channel patterns to sell the Lady Finger Bananas to the end consumers; 2) there were differences in marketing functions carried out by each marketing channel agency. The most marketing cost to carry out the marketing functions was incurred to the collecting traders of marketing channel II as much as IDR 34,393,000 per year; 3 ) the marketing of Lady Finger Banana in Arisan Gading Village was categorized as efficient.
\end{abstract}

\section{KEY WORDS}

Banana, marketing, efficiency, farming, village.

The potential of banana plants is very high to be developed intensively. Currently, bananas have become an export and import commodity in the international market. Domestically, there are quite a lot of industries that need bananas as their raw material so that it is considered that banana agribusiness has a high economic and social potential, particularly in efforts to improve community nutrition, expand employment, and increase farmers' income (Purwadi, 2009).

Banana marketing of Arisan Gading village consists of several marketing channels and involves several marketing institutions, namely collecting traders, wholesalers and retailers for marketing the bananas. The marketing channel in Arisan Gading Village consists of three marketing channels, namely two marketing institutions and one marketing. However, banana marketing in Arisan Gading village is not yet known as efficient or inefficient marketing. This is because the passing-through marketing flow and the activities of marketing functions carried out by different individuals to market their products to consumers can affect marketing costs, selling prices, purchase prices and profits received by farmers. All of these will affect efficient marketing. The study aimed to: describe the marketing channel on Lady Finger Banana farming in Arisan Gading Village, South Indralaya Subdistrict of Ogan lir District; describe the applied marketing functions and calculate the costs incurred for marketing functions in the marketing of Lady Finger Banana farming in Arisan Gading Village, South Indralaya Subdistrict of Ogan lir District; calculate the level of marketing efficiency of Lady Finger Banana farming in Arisan Gading Village, South Indralaya Subdistrict of Ogan lir District.

\section{METHODS OF RESEARCH}

This study used a survey method. The sampling technique was purposive sampling by selecting banana farmers in Arisan Gading Village and traders as the marketing institutions that market the farmers' banana products. The population was all farmers growing only Lady Finger Banana plants. The number of sample was 30 farmers selected from 110 households. The sample of marketing institutions was conducted by using the snowball sampling method. The marketing institutions involved in each marketing channel were those buying direct production from the farmers and continuing at the level of the marketing institution to the 
retailer. The number of sample of traders was 3 collecting traders, 1 wholesaler, and 6 retail traders.

Data Processing Method. To answer the first aim of the study on the marketing channel in Lady Finger Banana farming in Arisan Gading Village, South Indralaya Subdistrict, Ogan llir Regency, was carried out by tracing the marketing channels through the involved marketing institutions described descriptively based on the results of direct observations and interviews. The second goal was answered by using information gathered from the results of interviews with related institutions which were explained descriptively and calculating the costs mathematically as follows:

$$
M C=P F+S C+S F+T F+S G F+R C C+R M I C
$$

Where: $\mathrm{BP}=$ Marketing Costs (IDR/year); PF = Purchase Fee (IDR/year); SC = Sales Cost (IDR/year); SF = Storage Fee (IDR/year); BT = Transportation Fee (IDR/year); SGF = Standardization and grading fees (IDR/year); RCC = Risk Coverage Costs (IDR/year); $\mathrm{RMIC}=$ Real Market Information Costs (IDR/year).

The marketing margin was calculated based on a reduction in sales prices with purchase prices at each level of the marketing institution (Tjiptono, 2008). The formula is as follows:

$$
\mathrm{MM}=\mathrm{Pr}-\mathrm{Pf}
$$

Where: $\mathrm{MM}=$ Marketing Margin (IDR/bunch); $\mathrm{Pr}=\mathrm{X}$ market level selling price (IDR/bunch); $\mathrm{Pf}=\mathrm{X}$-level market purchase price (IDR/bunch).

Farmer's share is used to find out an efficiency of a trading activity by comparing the portion received by farmers to the price paid by each consumer (Istiyanti, 2010). The formula for calculating the farmer's share is as follows:

$$
F S=P F / P C \times 100 \%
$$

Where: FS = Farmer's Share (\%); PF = Product price at farmer level (IDR/bunch); HK = Product price at the end consumer level (IDR/bunch). formula:

The benefits gained by each involved marketing institution can be calculated using the

$$
\mathrm{MB}=\mathrm{TMM}-\mathrm{MC}
$$

Where: MB = Marketing Benefits (IDR/Year); TMR = Total Marketing Margin (IDR/Year); MC $=$ Marketing Costs (IDR/Year).

While the total marketing margin is obtained using the formula:

$$
\mathrm{TMM}=\mathrm{TS}-\mathrm{BF}
$$

Where: TP = Total Sales (IDR/Year); Bi = Buy Fee (IDR/Year)

Profit and cost ratios were used to find out the comparison of each existing marketing channel with the following formula:

$$
P R M C=K P / B P
$$

Where: PRMC = Profit Ratio of Marketing Costs; KP = X-level marketing profit (IDR/bunch); $\mathrm{BP}=\mathrm{X}$-level marketing costs (IDR/bunch). Criteria: PRMC $>1$ means that the marketing agency benefits; PRMC $=1$ means that the marketing agency breaks even; PRMC $<1$ means that the marketing agency loses.

According to Soekartawi (2002), calculating the value of marketing efficiency uses the following formula: 


$$
\mathrm{ME}=\mathrm{TMC} / \mathrm{TPV} \times 100 \%
$$

Where: $\mathrm{ME}=$ Marketing efficiency $(\%) ; \mathrm{TMC}=$ Total Marketing Costs (IDR/bunch); TPV = Total Product Value (IDR/bunch). Criteria: $0-33 \%$ is efficient; $34-67 \%$ is less efficient; 68 $100 \%$ is inefficient.

\section{RESULTS AND DISCUSSION}

Based on the results of interviews with farmer respondents in the village of Arisan Gading, the marketing process of Lady Finger Banana occurred in the village through three marketing channels. Marketing channel I is the one carried out from the farmers, collectors, wholesalers, retailers to the final consumer. The involved collecting traders are local residents of Arisan Gading Village and non-local residents, namely residents of neighboring villages such as Lubuk Sakti Village and Tebing Gerinting Village. They market the products of Lady Finger Banana to the wholesalers of Palembang City. The target markets for collectors were Pasar 10 Ulu, Jakabaring and $\mathrm{Km} 12$ markets. Marketing channel II is a channel that involves a collecting trader marketing agency and it sells it directly to the retailers without a large trader intermediary. The marketing process that is carried out from farmers to collectors is also the same as that of marketing channel I, that is, the collecting traders usually took the products directly and had buying and selling transactions to farmers in the plantation. The target markets for the collecting traders were the Sayangan Fruit Market and 16 llir Market. While marketing channel III is the one that the farmers directly sold to retailers. Retailers on this channel had the process of buying and selling transactions with the farmers the same as that of the collecting traders. However, unlike the marketing channels I and II, in the marketing channel III, the retailers only sold Lady Finger Banana in the markets located in Indralaya such as Pasar Meranjat, Pasar Kalangan, Pasar Indralaya, and Retailers who sold around the Arisan Gading Village, Tebing Gerinting, Lubuk Sakti, and Tanjung Raja. There were also various pedlars of Lady Finger Banana, some rode motorbikes with baskets of fruit, and some others walked with their lorries.

In marketing channel institutions, there were 17 farmers having marketing channels I and III whose total products were 3,135 bunches per season, with the percentage of farmers selling Lady Finger Banana through the marketing channel I as many as $81 \%$ or 2,560 bunches per season, and in the marketing channel III it was $19 \%$ or 575 bunches per season. There were 13 farmers having the marketing channels II and III whose total products were 2,080 bunches per season as many as 1,360 bunches per season or $65 \%$ in the marketing channel II, and in the marketing channel III, it was 720 bunches per season or $34 \%$.

The products of Lady Finger Banana of the farmers of Arisan Gading Village was mostly bought by the collecting traders, both from the marketing channels I and II and resold them to the wholesalers or retailers. There was a difference of selling prices among the farmers to the collecting traders in the marketing channels I, II and III. In the marketing channels I and II the price was IDR 30,000 , but in the marketing channel III it was IDR 20,000 . This is due to the differences in the quality of bananas. Every marketing channel agency I or II bought Lady Finger Banana, one bunch consisted of 7 to 9 tiers, while in the marketing channel III one bunch consisted of 5 to 6 tiers. The marketing channels I and II bought more bunches of bananas than that of the other marketing channel to mean that the collecting traders bought more from the farmers as well. Each retailer of marketing channels I and II sold the bananas both in the form of bunches and tiers. Generally consumers bought in the form of tiers sold at ranging prices from IDR 10,000 to IDR 15,000 per tier. Whereas the price per bunch was sold as much as IDR 100,000. In the sales volume of each marketing channel, the sales volume carried out by the farmers in each marketing channel pattern was not always constant because the sales transactions carried out by the farmers of Lady Finger Banana were sometimes done at the same time every week, while the selling volume would increase if the market demand increased; it was usually more than 60 bunches for each transaction. 
In the sales volume of each marketing channel, the sales volume carried out by farmers in each marketing channel pattern is not always constant because the sales transactions carried out by the farmers of Lady Finger Banana are sometimes done at the same time every week, while the selling volume will increase if the market demand increases, usually more than 60 bunches for each transaction.

The purchasing function was the purchase of Lady Finger Banana of Arisan Gading Village which was only carried out by the collecting traders, wholesalers and retailers. The purchase function is not carried out by the farmers because they were the producers of Lady Finger Banana. The marketing institutions that bought directly from the farmers were the collecting traders of marketing channels I and II, and the retailers of marketing channel III. The collecting traders of marketing channels I and II and the retailers of marketing channel III bought directly from the banana farmers. The purchase process started from the information conveyed by the farmers to the marketing institutions directly or indirectly. Then they had a sale and purchase transaction at the agreed time by meeting directly in the plantation. The marketing agency that bought bananas mostly from the farmers was the marketing channel I. The buying volume of the collecting traders from the farmers ranged from 10 to 20 bunches in one transaction of buying and selling. The transactions conducted by the marketing agencies with the farmers were generally carried out 3 to 5 times a week or the volume ranged from 40 to 70 bunches per week, whereas the wholesalers and retailers made purchases every day.

Farmers did not store their products in their houses because the marketing agencies bought the products directly in the plantation in the garden. The marketing agencies stored the products of Lady Finger Bananas in their own houses and stalls at which they sold and stored the bananas. Each marketing channel agency was charged some fee for storage. The amount of costs incurred by marketing institutions was influenced by the high volume of selling Lady Finger Bananas. As for the storage conducted by the collecting traders, they paid the costs of carbide, tarpaulin, and used newspapers. The wholesalers spent the costs of renting a place, tarpaulin, and sacks for storing the Lady Finger Banana supplies, while the retailers spent the costs of tarpaulins, sacks, and carbide.

The wholesalers did not carry out the transport function because the collecting traders directly came to the place where the wholesalers sold the Lady Finger Bananas at Pasar 10 Ulu Palembang and had direct transactions at the place of sale. The retailers of marketing channel II did not carry out transportation to make purchases because the collecting traders directly delivered to the point of sale, but the transport costs were charged to the retailer for transporting the Lady Finger Bananas to the merchant's house to store them for the next day sales. The collecting traders transported the Lady Finger Banana on their own to the wholesalers and retailers. The costs incurred by the marketing agency in the transportation function were the costs of fuel and vehicle depreciation. The collecting traders spent the most transportation cost because of the long distance that required more fuel.

Standardization and grading used by each marketing channel institution had different criteria in terms of fruit conditions, color, and size. The standardization used by the collecting traders referred to the condition that the fruit had to be very raw at the time of harvesting. The peel of the fruit had to be hard and solid. The peel color was still light green indicating that the fruit could be ripened using carbide for two to three days. If the peel color was whitish or dark green, it took only one to two days. There were a few differences of the collecting traders of marketing channels I and II because it took them longer time to reach their consumers so that so that the collecting traders of the marketing channel I would choose very raw with light green fruit to be sold to wholesalers. Meanwhile, the collecting traders of marketing channel II chose the whitish or dark green fruit to be sold to the retailers. Standardization of the marketing channel III did not pay too much attention to the level of fruit ripeness or fruit peel color because the Lady Finger Bananas to be sold did not take a long time to reach the consumers

The market information needed by the farmers and marketing institutions can be received through direct verbal communication. On average the determination of the price of Lady Finger Bananas in Arisan Gading Village between the farmers and the traders was in 
accordance with the market condition and information obtained by the traders, though the truth of the information was sometimes unsure. Marketing institutions generally had a broader range of information than farmers because the traders had many sources of information from fellow traders, either traders in the market or other banana agents.

Marketing institutions between fellow traders or between traders and farmers also seek information in advance by contacting their fellow traders or farmers in several areas that produced Lady Finger bananas concerning the prevailing buying and selling prices in order to further determine the buying and selling transaction of Lady Finger Banana. Market information is indispensable when approaching certain days such as Chinese New Year or other Chinese holidays that usually demand very highly for Lady Finger bananas causing their price to rise. Unlike the case when other seasonal fruits such as durian, duku, and rambutan were on the market, the price of bananas tended to decrease and this condition allowed the traders to quickly exchange information to find out how much decrease was the price.

The risks faced in marketing Lady Finger Bananas covered damages due to physical functions of the storage and transportation. Consequently, the decrease of the selling price of the product resulted in reduction of the marketing profits. The risk insurance cost of sales is the loss caused by the unsold fruit and the cost of reducing the selling price of fruit that does not pass the selection. The cost of loss of the unsold Lady Finger Bananas was caused by the rotten or damaged fruit, meanwhile the cost of price reduction of the unselected fruit resulted from the defects occurred to the Lady Finger Banana caused by pest attacks such as black spots, imperfect fruit shape, and too small fruit size.

The marketing cost incurred by each marketing channel was different because there were more and more marketing agencies involved that the cost incurred for each marketing function became greater. Likewise the reach of consumers, the marketing channel I marketed in the city of Palembang so that the transportation cost became the most expensive in the marketing process. The least cost of marketing was spent in the marketing channel III because the institutions involved were only retailers. Besides, the transportation process did not take much time because it was only around Indralaya that cost less money to spend.

The marketing margin of marketing channels I and II had the same value because the prices at the farmer level and consumer level were the same even though there were differences in the number of the marketing institutions involved. In the marketing channel I, the collecting trader sold the fruit to the wholesaler at a price of IDR 50,000 and resold it to the retailer at a price of IDR 70,000. Meanwhile the collecting traders of marketing channel II sold to the retailers at a price of IDR 65,000 . However, the two marketing channels had the same purchase price at the consumer level. So that the marketing channel I and II margins are the same. Marketing channel III had a smaller margin because the selling price of bananas from farmers was the cheapest involving only one marketing agency. However, there were differences in terms of the characteristics of Lady Finger Banana, thus causing the selling prices to consumers to be much different from those of the marketing channels I and II.

The marketing costs of the collecting traders of the marketing channel I were smaller than that of the marketing channel II even though the marketing margin was greater in the marketing channel II. This way, the gained benefits were greater because it was influenced by a large marketing margin. The marketing institution with the smallest profit was the retailers of marketing channel III and the marketing costs incurred every year were also the least. However, due to the small sales volume of bananas which caused the total annual marketing margin was small so that the profits obtained were small.

The marketing channel I received a slightly smaller profit than the marketing costs incurred. This was due to the high transportation costs spent by the collecting traders and the cost of standardization and grading incurred to the wholesalers to pay for labor. Nevertheless, the ratio of profits gained was almost as large and not too much different from the marketing costs incurred. In marketing channel III, the value of the ratio of profit and marketing costs was the highest compared to other marketing channels. In addition to the 
least involved marketing institutions, the costs incurred for carrying out the marketing functions were the least. In consequence, the more marketing institutions were involved, the less the value of the profit and marketing costs would be. In each Lady Finger Banana marketing channel pattern, it can be concluded that the higher the marketing costs are, the lower the profit and marketing costs will be.

The marketing channel III was the portion received by the farmers with the largest percentage of $40 \%$, meaning that farmers received almost half of the purchase price paid by the final consumers. It was affected by the small number of the involved marketing institutions and the selling price of Lady Finger Banana at the farmer's level. However, this difference existed since the sold Lady Finger Bananas had a lower quality than those in the marketing channels I and II. Based on the three types of banana marketing channels in Arisan Gading Village, the farmer's share indicator was the most profitable in the marketing channel III.

The efficiency value of each banana marketing channel showed that each marketing channel was categorized efficient. The marketing channel I involved the most marketing institutions but had the least efficiency value. However, this was due to the magnitude of the total value of the product produced. Likewise the marketing channel III, even though only one marketing agency was involved but the resulting efficiency value was greater. This resulted from a small selling volume that caused a low total product value. In conclusion, the least involved marketing institutions might be the least efficient because it was still influenced by the amount of the annual sales volume. Conversely, even though the involved marketing institutions were greater in number, if the selling volume was large, the efficiency value would be smaller.

\section{CONCLUSION}

The marketing channel of Lady Finger Banana in Arisan Gading Village had three marketing channel patterns to sell the Lady Finger Bananas to the end consumers. The marketing channel that was mostly used by the farmers was the marketing channel III.

There were differences in marketing functions carried out by each marketing channel agency. In the exchange function only the farmers did not carry out the purchase function. In the physical function, the farmers did not carry out the transportation and storage functions, while the marketing agency of wholesalers did not carry out the transportation function. The most marketing cost to carry out the marketing functions was incurred to the collecting traders of marketing channel II as much as IDR 34,393,000 per year.

The marketing channels with the biggest margin occurred to the marketing channels I and II. Judging from the farmer's biggest share in marketing channel III, which was $40 \%$, the profit ratio and marketing costs were the most profitable in marketing channel III, which is 1.51 and the smallest efficiency value was in marketing channel I which was $17.1 \%$. Therefore, the marketing of Lady Finger Banana in Arisan Gading Village was categorized as efficient.

\section{RECOMMENDATIONS}

It is recommended that the Lady Finger Banana farmers in Arisan Gading Village need to find price information at the consumer level to maintain the selling price of Lady Finger Banana and maintain the marketing process to the collecting traders so that there is no price imbalance between farmers and end consumers.

For the involved marketing institutions of Lady Finger Bananas such as collecting traders, wholesalers, and retailers, they need to minimize the marketing costs so that the profit and marketing cost ratio increases.

For further researchers, it is expected that they study the strategy of developing the Lady Finger Banana in the city of Palembang City and Ogan Ilir District. 


\section{REFERENCES}

1. Dinas Tanaman Pangan dan Holtikultura (2013). www.holtikultura.pertanian.go.id. (diakses 20 April 2018).

2. Firdaus M (2009). Manajemen Agribisnis. Bumi Aksara, Jakarta.

3. Istiyanti E (2010). Efisiensi Pemasaran Cabai merah keriting di Kabupaten Sleman. Jurnal Pertanian MAPETA 12: 72.

4. Purwadi T. (2009). Potensi Usahatani Pisang Ambon melalui Program Primatani. Fakultas Ekonomi dan Manajemen: Institut Pertanian Bogor. Rohim A, 2007. Pengantar Ekonomika Pertanian. Jakarta: Penebar Swadaya.

5. Rokhman, 2017. Analisis Efisiensi Pemasaran Pisang Kepok Di Kabupaten Seruyan. UNES Journal of Agricultural Scienties 1: 1-5.

6. Soekartawi (2002). Agribisnis Teori dan Aplikasinya. PT Raja Grafindo Persada, Jakarta. 